\title{
Hydrodynamic regulation of salt marsh contributions to aquatic food webs
}

\author{
Ronald Baker $^{1,2, *}$, Brian Fry ${ }^{3,5}$, Lawrence P. Rozas ${ }^{4}$, Thomas J. Minello ${ }^{1}$ \\ ${ }^{1}$ NOAA National Marine Fisheries Service, SEFSC, Galveston Laboratory, 4700 Avenue U, Galveston, Texas 77551, USA \\ ${ }^{2}$ Centre for Tropical Water and Aquatic Ecosystem Research, School of Marine and Tropical Biology, James Cook University, \\ and CSIRO Land and Water, ATSIP Building, James Cook University, Townsville, Queensland 4811, Australia \\ ${ }^{3}$ Department of Oceanography and Coastal Sciences, LSU, Baton Rouge, Louisiana 70803, USA \\ ${ }^{4}$ NOAA National Marine Fisheries Service, SEFSC, Estuarine Habitats and Coastal Fisheries Center, \\ 646 Cajundome Boulevard, Lafayette, Louisiana 70506, USA \\ ${ }^{5}$ Present address: Australian Rivers Institute, Griffith University, 170 Kessels Road, Brisbane, Queensland 4111, Australia
}

\begin{abstract}
Vegetated salt marsh habitats are widely considered critical for supporting many species of nekton, yet direct evidence of the processes controlling marsh habitat use for most species remains elusive. We related salt marsh flooding patterns and nekton trophic dynamics among 14 sites spanning $2500 \mathrm{~km}$ across the northern Gulf of Mexico (GoM) and southern Atlantic coasts of the USA. Functional access for nekton to marsh vegetation (edge flooded to $\geq 5 \mathrm{~cm}$ depth) ranged from $<40 \%$ of the time at some central GoM sites to $>90 \%$ access in the western GoM and Pamlico Sound. Food web mixing models based on stable isotope analysis show that the importance of Spartina trophic support for common nekton may be regulated by the duration of marsh surface flooding. In particular, the potential contribution of Spartina production was positively related to indices of marsh surface flooding for brown shrimp Farfantepenaeus aztecus, white shrimp Litopenaeus setiferus, small ( $\leq 60 \mathrm{~mm}$ carapace width) blue crabs Callinectes sapidus, grass shrimp Palaemonetes pugio, and killifish Fundulus heteroclitus/grandis. The value of Spartina salt marsh production to several common species of nekton appears to depend, at least in part, on direct access to the vegetated marsh surface, which is regulated by hydrodynamics. Hence, the substantial geographic and temporal variability in marsh flooding regulates the functional roles and value of these tidal wetlands for aquatic organisms.
\end{abstract}

KEY WORDS: Stable isotope · Nursery function - Essential fish habitat - Trophic dynamics · Hydroecology $\cdot$ Tidal wetlands

\section{INTRODUCTION}

Salt marshes are considered essential habitat for a great diversity of aquatic organisms (Connolly 1999, Cattrijsse \& Hampel 2006), and particularly important in supporting some commercial fisheries (Turner 1977, Boesch \& Turner 1984, Deegan et al. 2000, Zimmerman et al. 2000). These wetlands are believed to provide a refuge from predators for vulnerable nekton able to access the complex structure of the vegetated marsh surface (Minello et al. 1989). Salt marshes may also contribute to secondary production in food webs of adjacent aquatic habitats via direct foraging migrations (Weisberg \& Lotrich 1982), trophic relay (Kneib 1997, 2000), and outwelling of detrital material (Teal 1962). Many species of nekton occupy the surface of flooded marshes along the Gulf of Mexico (GoM) (Peterson \& Turner 1994, Minello 1999) and Atlantic coasts (Kneib 1991) of the USA, but alternative habitats also potentially contribute many of the resources nekton use in these systems (Kneib 1997, Cicchetti \& Diaz 2000, Minello et al. 2008). For example, much of the trophic support for brown shrimp populations in Louisiana estuaries may 
come from open water habitats (Fry 2008). As such, the significance of the vegetated marsh as a foraging ground remains uncertain.

Spartina alterniflora (hereafter Spartina) salt marshes in the USA are believed to fuel detritusbased food webs that support consumers in adjacent estuarine and marine systems (Teal 1962, Peterson et al. 1980, 1986). Recent studies suggest that marsh detritus from outwelling rapidly diminishes with distance from the marsh, and that production transfers to adjacent ecosystems occur mainly via trophic relay or animal migrations (Deegan et al. 2000, Kneib 2000). Within the marsh complex itself, stable isotope studies have revealed other significant sources of primary production such as benthic microalgae and phytoplankton (Sullivan \& Moncreiff 1990, Currin et al. 1995, 2011), yet Spartina also contributes to the trophic support of a variety of estuarine consumers occupying the marsh complex (Currin et al. 2003, Galvan et al. 2008).

Whether intertidal marsh production is acquired by aquatic consumers during direct foraging migrations onto the marsh surface, through intermediate consumers in trophic relays, or via outwelling of detritus, hydrology plays a central role in regulating this transfer. Marsh flooding dynamics dictate when, for how long, and how often aquatic organisms can directly use the marsh surface and the resources provided there. The significance of hydrology in regulating the functional roles of intertidal marsh habitats is recognized (Rozas 1995, Connolly 1999, Kneib 2000), yet few studies have explicitly examined the relationship between hydrodynamics and this provisioning function for nekton. Some sitespecific research has shown that a few species of nekton typically have fuller guts following high tide when the marsh is accessible (Weisberg et al. 1981, Ryer 1987, Rozas \& La Salle 1990, Potthoff \& Allen 2003 ), and that some nekton species grow faster when they have access to the marsh surface than when restricted to subtidal habitats (Weisberg \& Lotrich 1982, Javonillo et al. 1997, Minello et al. 2003, Shervette \& Gelwick 2008). The generality of these findings among nekton species and among other geographic regions with differing hydrodynamic patterns of marsh flooding, however, remains unknown. Thus, despite significant advances in many areas of salt marsh ecology (Kneib 1997, 2000, Rountree \& Able 2007), our understanding of the functional values of salt marshes in many ways is based on indirect evidence, and remains as generalized paradigms applied broadly to vegetated wetlands across the globe (Sheaves et al. 2006).
Effective management of salt marsh habitats and protection of their ecosystem services require an understanding of the processes that support these services, and how these functions vary geographically. The aim of our study was to explore relationships between food web structure (measured through stable isotope analysis) and hydrodynamic variables that may regulate production transfers between the marsh surface and adjacent waters, across a broad geographic range with widely variable marsh flooding patterns. Despite the utilization of multiple sources of nutrition, variability in animal movements, and the dynamics of biological communities, we expected the effects of hydrology on trophic dynamics to be detectable in these analyses. Our primary hypothesis was that the nekton species commonly found in high densities on the marsh surface are there, at least in part, to forage on Spartinabased food chains, and that hydrology regulates access to marsh resources. We predicted significant relationships between contributions of Spartina production and the amount of time available for nekton to access the marsh surface.

\section{MATERIALS AND METHODS}

\section{Study sites}

We sampled 15 marsh sites spanning $>2500 \mathrm{~km}$ of the northern GoM and southern Atlantic coasts of the USA, from Aransas Bay, Texas, to lower Chesapeake Bay in Virginia (Fig. 1). Sampling was conducted between 2 and 18 June 2008, with each site visited for $<4 \mathrm{~h}$ on one day. All sites were Spartina alterniflora-dominated marshes in the lower reaches of their respective estuaries and located near active tide gauges, which allowed us to develop flooding indices. Each site also had an open and unimpeded connection to the tide gauge and the ocean. A detailed description of the study sites and site selection rationale is provided in Minello et al. (2012).

\section{Flooding indices}

Details of the field techniques, data analysis, and a description of geographic patterns in marsh flooding dynamics among the sites are provided in Minello et al. (2012). Briefly, marsh-surface elevations were measured along 7 replicate transects located randomly within ca. $1 \mathrm{~km}$ of non-erosional shoreline at each site. Each transect was $50 \mathrm{~m}$ long $(30 \mathrm{~m}$ in open 


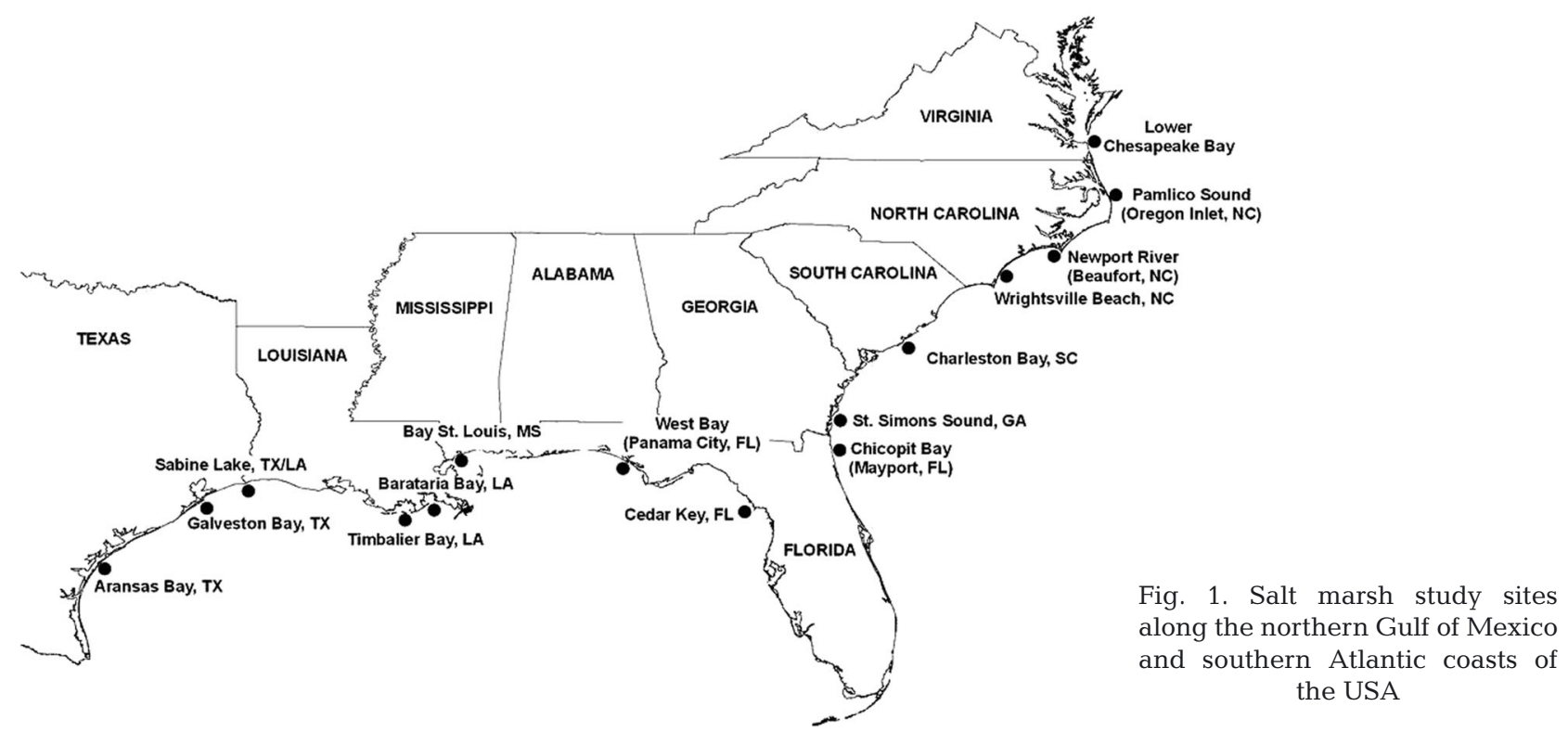

water and $20 \mathrm{~m}$ on the marsh surface) and located perpendicular to the shoreline. For the indices used in this study, elevations were recorded at the marsh edge, and at $1 \mathrm{~m}$ intervals for the first $10 \mathrm{~m}$ onto the marsh surface. We defined the marsh edge as the most seaward culms of Spartina. Elevations were related to water levels on nearby tide gauges so that patterns of marsh surface flooding could be derived using historic hourly water level data from the gauge.

Nekton can penetrate well onto the marsh surface (Kneib \& Wagner 1994); however, where it has been investigated, the highest densities of transient species usually occur within the first few $(<10)$ meters of marsh vegetation (Peterson \& Turner 1994, Minello et al. 2008). Although we expect that spatial patterns of marsh use by nekton may vary across our study area, driven in part by differences in hydrology, the first few meters of marsh vegetation are likely the most functionally relevant for many species. The NOAA database of nekton densities from marsh edge habitats of Galveston Bay, Texas, indicates that nekton begin to occupy the marsh edge once the water depth reaches $5 \mathrm{~cm}$ (T. J. Minello unpubl. data). We developed 2 flooding indices based on this information. We calculated an edge-flooded index (EFI) defined as the duration that the marsh edge would be flooded to $\geq 5 \mathrm{~cm}$ depth. This simple index allows comparison among sites of the total amount of time when at least some marsh surface is accessible to nekton. However, because the elevation profiles and hence flooding patterns of the marsh surface inland from the marsh edge vary among sites (Minello et al. 2012), flooding of the marsh edge alone may not reflect functional access farther into the marsh. Thus we also computed a flood area index (FAI), defined as the extent to which the first $10 \mathrm{~m}$ of marsh surface is flooded to $\geq 5 \mathrm{~cm}$, where $100 \%$ indicates that the entire first $10 \mathrm{~m}$ of marsh vegetation was continuously flooded to a depth of $\geq 5 \mathrm{~cm}$. Using our linear elevation profiles, we assumed that nekton access the marsh surface linearly perpendicular to the marsh edge, rather than via drainage systems or other pathways. Under this assumption, any high points along the elevation profile, such as elevated berms near the marsh edge, must be overtopped by water to allow nekton access farther into the marsh. The elevation profiles of most sites showed an increase in elevation from open water to the relatively flat marsh platform within the first $10 \mathrm{~m}$ of vegetation (Minello et al. 2012), supporting our assumption that flooding indices for this part of the marsh accurately reflect marsh-surface accessibility. The only site with a pronounced berm was Timbalier Bay, Louisiana.

Many nekton species exhibit diel activity patterns (Wickham \& Minkler 1975, Weisberg \& Lotrich 1982, Ryer 1987). Accordingly, we calculated separate flooding indices for night (the hourly water level readings from 19:00 to 06:00 $\mathrm{h}$ inclusive) and day $(07: 00$ to $18: 00 \mathrm{~h})$. Isotope turnover times in slowgrowing muscle tissues are such that isotope values integrate the diet over a period of a few months (Buchheister \& Latour 2010). In fast-growing nekton, however, muscle biomass is dominated by new growth, and thus, isotope values integrate production sources over shorter time frames (Hesslein et al. 1993). Our target nekton included both fast-growing juveniles (e.g. penaeid shrimp) and reproductively mature adults (e.g. grass shrimp). Therefore, we calculated the flooding indices for both day and night over periods of $3 \mathrm{mo}, 1 \mathrm{mo}$, and $1 \mathrm{wk}$ prior to the sam- 
pling date at each site. This step generated many closely related hydrodynamic indices. Tidal amplitude and flooding frequency may also regulate the functional role of salt marsh habitats for nekton. However, amplitude and flooding frequency are strongly correlated, and negatively correlated with measures of flooding duration (Minello et al. 2012). Because of this strong relationship among hydrological variables, we restricted our analyses to indices of flooding duration. To explore relationships between hydrodynamics and food web structure, we looked for consistent correlations between flooding indices and the potential contribution of Spartina production to consumers (see 'Relating trophic support of nekton to hydrodynamics' below).

\section{Food web sampling}

The nekton assemblage that occupies marsh systems across the geographic range of our study area remains broadly similar (Rountree \& Able 1992, Kneib \& Wagner 1994, Rozas et al. 2007), with the replacement of some species by closely related and ecologically similar congeners (e.g. Fundulus grandis and F. heteroclitus, Gonzalez et al. 2009). To compare marsh trophic structure across this broad region, we aimed to produce food webs with dominant producers and consumers representing the key functional groups common to all sites, rather than trying to sample all possible producers and consumers. Generalist consumers of fisheries significance that we targeted included brown shrimp Farfantepenaeus aztecus, white shrimp Litopenaeus setiferus, and blue crab Callinectes sapidus. To represent planktonic production, we targeted filter feeding invertebrates and planktivorous fishes: mussels Gukensia demissa, oysters Crassostrea virginica, barnacles Balanus venustus, silversides Menidia beryllina and $M$. menidia, and anchovies Anchoa mitchilli and a few $A$. hepsetus. Mullet Mugil cephalus and M. curema were present across all sites and were collected to represent phyto-detritivores/microphytobenthos (MPB) feeders. Targeted marsh surface specialists included killifish Fundulus grandis and F. heteroclitus, which were combined as a single functional group hereafter referred to as Fundulus, grass shrimp Palaemonetes pugio, and marsh periwinkles Littoraria irrorata. We collected 3 spatially separate (100s of m) replicate samples of each targeted consumer, and each replicate sample included 15 individuals of similar size where possible. Nekton samples were collected with cast nets, minnow traps, dip nets, and seine nets. All samples were placed in a saline ice-slurry and then frozen for later laboratory processing.

We targeted the 3 production sources that dominate primary production at salt marshes throughout the region, namely Spartina alterniflora, MPB, and phytoplankton (Sullivan \& Moncreiff 1988). We sampled replicates of both live and standing dead Spartina from each of 3 spatially separate locations at each marsh site. Each replicate included 5 pooled leaves, 1 from each of 5 different stems. Obtaining pure samples of phytoplankton and MPB for isotopic analysis is difficult (Currin et al. 2003, Oakes et al. 2005). Even if pure samples collected at one point in time were obtainable, short generation times and high isotope turnover rates of microalgae may render isotope values of these producers poor end-members for consumers that integrate spatio-temporal variability in source values over longer time periods (Cabana \& Rasmussen 1996, Post 2002). Therefore, we used a combination of direct samples of these producers, samples of representative consumers, and published values to define end-members representing planktonic and MPB sources. We collected 1 sample of suspended particulate material (SPM) to represent phytoplankton at each marsh by filtering the water pumped for $5 \mathrm{~min}$ from the surface $(\sim 20 \mathrm{~cm})$ layer of open water adjacent to the marsh. The fraction of SPM retained between 250 and $125 \mu \mathrm{m}$ sieves was used for analysis. Although this fraction would contain predominantly zooplankton as well as large phytoplankton, we hoped to eliminate some of the contamination by suspended sediment and detritus particles that would occur in finer fractions of suspended materials. The SPM data were combined with data from plankton consumers to estimate phytoplankton $\delta^{13} \mathrm{C}$ source values in mixing models based on $\delta^{13} \mathrm{C}$ and $\delta^{34} \mathrm{~S}$ (see 'Isotope mixing models' below). Because these isotopes show only minor trophic fractionation (Peterson \& Fry 1987), the inclusion of some zooplankton in our SPM samples would have negligible effects on the final source values. To sample MPB, we collected ca. $100 \mathrm{ml}$ of surface ( $<5 \mathrm{~mm}$ depth) sediments from the substrate adjacent to the marsh edge, targeting (when possible) areas with a visible layer of flora on the surface. MPB samples were taken to the laboratory for acetone extraction of chlorophyll. We used $\delta^{13} \mathrm{C}$ values of the extracts as a proxy for the MPB community values (see 'Sample processing and isotope analysis' below). Full replication of pooled samples was not possible for all taxa at all sites (Table S1 in the Supplement at www. int-res.com/articles/suppl/m490p037_supp.xls). 


\section{Sample processing and isotope analysis}

Spartina leaves were scraped with a scalpel to remove any epiphytes, sediments, or debris, although little was visible on any leaves. Clean white muscle was dissected from fishes, from the abdomen of shrimps, and from legs of crabs. The adductor muscle was removed from bivalves, while the muscular foot of Littoraria was dissected out for analysis. Barnacles were removed from their shells and analyzed whole. All samples were rinsed in tap water and then soaked in distilled water for $>30$ min to remove salts, and dried for $48 \mathrm{~h}$ at $60^{\circ} \mathrm{C}$. Samples were then ground to a fine powder using Wig-L-Bug automated grinding mills and weighed into tin cups for analysis. Carbonate contamination of barnacle and SPM samples was tested using $1 \mathrm{~N} \mathrm{HCl}$, and if found was removed by overnight acidification, rinsing, and re-drying.

Various techniques have been used to sample MPB for isotope analysis, most of which are biased towards particular components of the MPB community (Oakes et al. 2005). We performed acetone extraction on the MPB sediment samples to extract chlorophyll for analysis as a proxy for the MPB community $\delta^{13} \mathrm{C}$ values (Demopoulos et al. 2008). Approximately $10 \mathrm{ml}$ of wet sediment were added to $10 \mathrm{ml}$ of undiluted reagent-grade acetone, shaken thoroughly, and placed into a dark refrigerator for $24 \mathrm{~h}$. The acetone was then decanted and filtered through pre-combusted GF/F filters to remove any remaining sediment particles, and evaporated in a fume hood. The remaining residue was dried at $60^{\circ} \mathrm{C}$ for $48 \mathrm{~h}$ and scraped from the vial for analysis. Our acetone extracts provide a simple proxy for the MPB community $\delta^{13} \mathrm{C}$ available to consumers at each site.

Isotope values were measured with an automated system that included an elemental analyzer coupled to an isotope ratio mass spectrometer for coupled measurements of $C, N$, and $S$ isotope values from single samples (Brand 1996, Fry 2007). Replicate C, N, or $\mathrm{S}$ isotope analyses usually agreed by $0.2 \%$ or better. Results are given in per mille units as $\delta^{13} \mathrm{C}$ versus Vienna Pee Dee Belemnite, $\delta^{15} \mathrm{~N}$ versus air $\mathrm{N}_{2}$, and $\delta^{34} \mathrm{~S}$ versus Vienna Canyon Diablo Troilite. Highpurity $\mathrm{CO}_{2}, \mathrm{~N}_{2}$, and $\mathrm{SO}_{2}$ in laboratory gas tanks were calibrated with known standards and used as working reference materials (Fry 2007).

\section{Isotope mixing models}

We used $\delta^{13} \mathrm{C}$ and $\delta^{34} \mathrm{~S}$ values in 3 -source mixing models to estimate the potential contributions of Spar- tina, MPB, and phytoplankton production to our consumers. These isotopes undergo minimal trophic fractionation (Peterson \& Fry 1987) and provide the greatest resolution for distinguishing production sources (Connolly et al. 2004). $\delta^{15} \mathrm{~N}$ data were not used in mixing models because the larger, variable, and often poorly-known trophic fractionations that $\mathrm{N}$ undergoes complicates its use in identifying sources (Peterson \& Fry 1987, Fantle et al. 1999, Caut et al. 2009). N data were analyzed separately to estimate trophic level. Trophic level serves as a metric of community dynamics, which might vary across sites and add noise to the models relating marsh use to hydrology.

We followed a stepwise approach to defining the end-member values for our 3-source models in $\delta^{13} \mathrm{C}-\delta^{34} \mathrm{~S}$ biplots, using both bottom-up and topdown inference (Wissel \& Fry 2005, Fry 2013). First, we compiled published values for each of the sources from salt marshes along the GoM and Atlantic coasts of the USA to determine the predicted range within which the values would likely fall at each of our sites. Our primary producer isotopic data broadly agreed with previously published values (Figs. $2 \& 3$ ). Next, we adjusted the end-member values on a site by site basis using the available producer data for each site. Spartina $\delta^{13} \mathrm{C}$ values were fixed first since these were based on the most consistent isotope data available for the producers, with minimal variation between live and standing dead, and among sites (Fig. 3). MPB $\delta^{13} \mathrm{C}$ was determined from the acetone extracts, while $\delta^{13} \mathrm{C}$ for the phytoplankton end-member was set to enclose our data on SPM, filter-feeding invertebrates, and planktivorous fishes.

Defining $\delta^{34} \mathrm{~S}$ values for the end-members required use of both the available producer and consumer isotopic data at each site, as well as published and theoretical values. Spartina $\delta^{34} \mathrm{~S}$ was initially set as the mean of the values from standing dead plants. The $\delta^{34} \mathrm{~S}$ of our SPM samples was much more depleted than expected for phytoplankton, probably due to contamination by inorganic sulfides from sediments (Currin et al. 2003). Hence, for phytoplankton, we assumed a $\delta^{34} \mathrm{~S}$ value of $+18 \%$ based on the values of sulfate in seawater and fractionation in marine phytoplankton (Trust \& Fry 1992). Different components of the MPB community variously use isotopically heavy sulfates from the water column, and light sulfides from porewater (Peterson et al. 1986). Because living Spartina also incorporates both sulfur sources (Carlson \& Forrest 1982), we used the mean $\delta^{34} \mathrm{~S}$ value for live Spartina at each site as our starting point for MPB $\delta^{34} \mathrm{~S}$. From these starting values, only small (mostly $<2 \%$ ) adjustments were made to pro- 

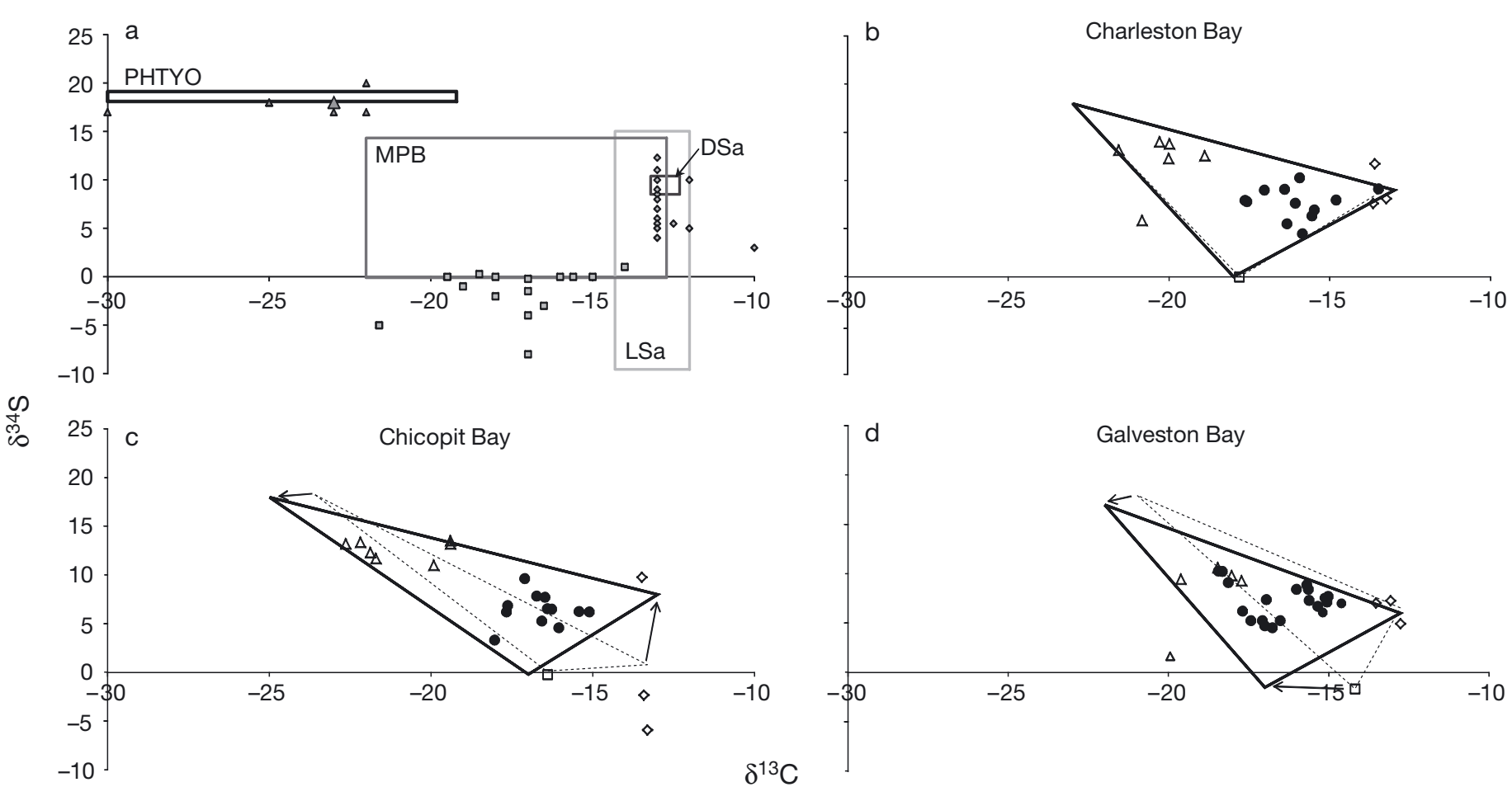

Fig. 2. Setting $\delta^{13} \mathrm{C}$ and $\delta^{34} \mathrm{~S}$ isotope source values for 3-source mixing models of salt marsh food webs along the Gulf of Mexico and Atlantic coasts of the USA. (a) Boxes indicate range in published theoretical values or empirical data for these regions: PHYTO: phytoplankton (usually measured as suspended particulates); MPB: microphytobenthos; LSa (DSa): live (standing dead) Spartina alterniflora. Data points are end-member values used in 3-source mixing models for each site: triangles: phytoplankton; squares: MPB; diamonds: DSa. Literature values from Fogel et al. (1992), Trust \& Fry (1992), Currin et al. (1995) and studies cited therein, Riera et al. (2000), Wainright et al. (2000), Currin et al. (2003), Galvan et al. (2008). (b-d) Representative site food webs; diamonds: DSa; squares: MPB acetone extract $\delta^{13} \mathrm{C}$, LSa mean $\delta^{34} \mathrm{~S}$ to estimate MPB isotopic values; triangles: suspended particulate material and plankton consumers; solid circles: target consumers (fishery species and marsh-surface specialists). Large dashed triangles indicate initial source values based on published and local site producer data, solid-line triangles indicate final source values adjusted to enclose local site consumer data (as indicated by arrows in c and d). The final source values for all sites indicated by data points in (a) include the source values shown as the apices of the final (solid-line) mixing triangles in (b-d). Site food webs for all sites are presented in Fig. S1 in the Supplement

duce 3-source models that enclosed most consumers at each site (Fig. 2b-d; Fig. S1 in the Supplement at www.int-res.com/articles/suppl/m490p037_supp.xls) (Post 2002). Fractional contributions for each of the 3 sources were calculated with this triangle approach (Fry 2013). Amongst the consumers we sampled, only the gastropod Littoraria irrorata had isotope values that consistently fell outside the final mixing triangles, and along with a few samples of small and large Mugil spp., source contributions for these gastropods could not be estimated from the mixing models (Fig. 3, Fig. S1).

\section{Consumer trophic levels}

We estimated the trophic level of consumers at each site using $\delta^{15} \mathrm{~N}$ data. We examined only those consumers that fit our mixing models (i.e. penaeid and grass shrimps, small blue crabs, and killifish), and not those used specifically to define end-member values (i.e. planktivores). We had few data on source $\delta^{15} \mathrm{~N}$ values, so we used Farfantepenaeus aztecus, the most widespread generalist omnivore sampled (Table S1), as a baseline to estimate trophic level of other consumers in the community (Fry \& Chumchal 2012). We assigned it a trophic level of 2.5 (McTigue \& Zimmerman 1998, Fry et al. 2003), and calculated trophic levels for other consumers using trophic enrichment factors for $\delta^{15} \mathrm{~N}$ of both $2.2 \%$ (McCutchan et al. 2003) and 3.4\%o (Post 2002).

\section{Relating trophic support of nekton to hydrodynamics}

To explore relationships among the marsh flooding metrics and the potential contributions of Spartina to 

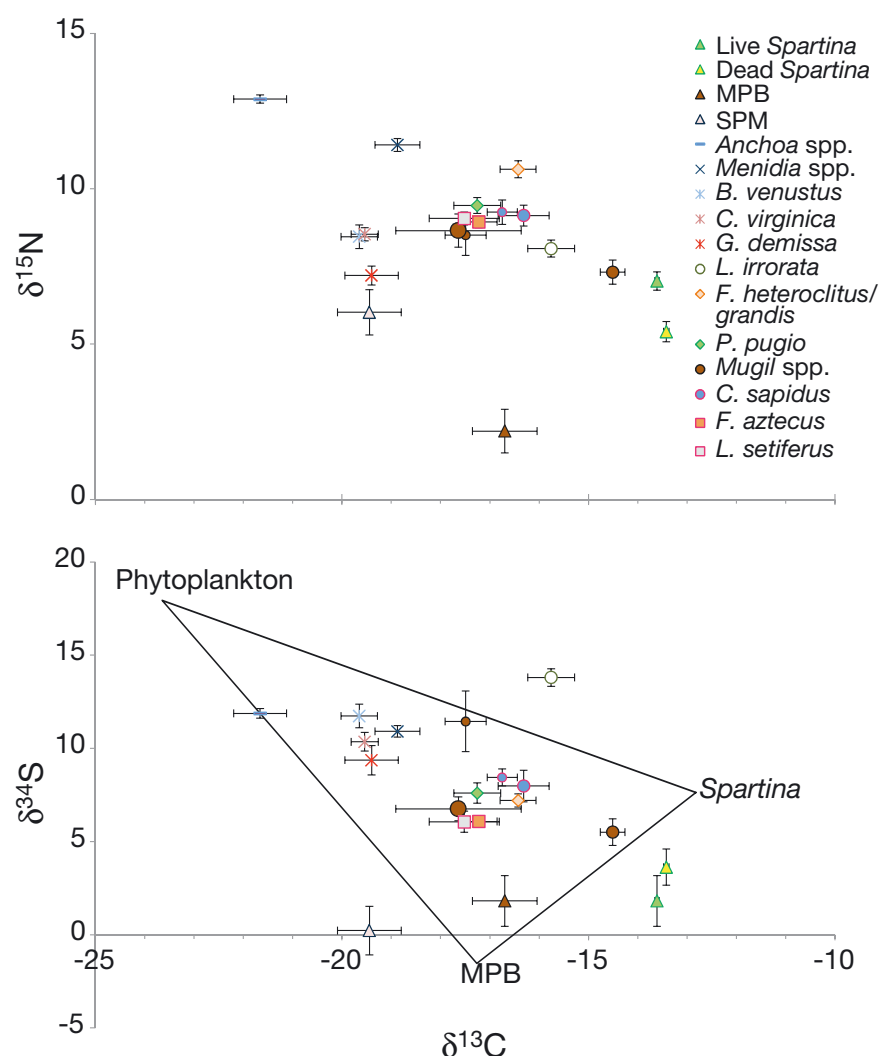

Fig. 3. Mean $( \pm 1 \mathrm{SE})$ isotopic values for producers and consumers at 15 salt marshes across the northern Gulf of Mexico and southern Atlantic coasts of the USA. Sample sizes are provided in the 'totals' column of Table S1 in the Supplement (at www.int-res.com/articles/suppl/m490p037_supp. $\mathrm{xls}$ ). Large triangle in lower panel indicates the mean source values determined across all sites (excluding West Bay, Florida). Data for microphytobenthos (MPB) $\delta^{15} \mathrm{~N}$ in upper panel based on literature values summarized in Fig. 2a because no $\delta^{15} \mathrm{~N}$ values are obtainable from acetone extracts used to measure MPB $\delta^{13} \mathrm{C}$. Similarly, $\delta^{34} \mathrm{~S}$ values for MPB in lower panel were those measured for live Spartina as explained in the 'Materials and methods'. Symbol size for Callinectes sapidus and Mugil spp. indicates size classes: $C$. sapidus, small: $\leq 60 \mathrm{~mm}$ carapace width, large: $>60 \mathrm{~mm}$; Mugil spp. small: $<50 \mathrm{~mm}$ total length, medium: 50-100 mm,

large: >100 mm. SPM: suspended particulate material

consumers, we calculated the mean values for each flooding metric among the replicate elevation transects at each site and the mean source contribution from replicate isotope samples of each consumer at each site. We constructed a correlation matrix including the flooding metrics and source contributions. We restricted inclusion of consumers in the correlation matrix based on a priori expectations that direct access to the marsh surface for feeding would be particularly important to a subset of the species we sampled (marsh-surface specialists, nekton of fishery significance), and excluded those that were used specifically in determining source end-member val- ues in the mixing models (filter-feeders and planktivores). Flooding metrics were considered highly correlated when $r>0.9$. When at least 2 of a group of highly-correlated flooding metrics were also correlated with Spartina contributions to consumers $(\mathrm{r}>0.5)$, we examined the relationship using regressions and present representative models for each consumer.

We used $\delta^{15} \mathrm{~N}$ values to examine the relative trophic level of individual species among sites for those species that showed spatial patterns in the potential contributions of Spartina production. A negative relationship between $\delta^{13} \mathrm{C}$ and $\delta^{15} \mathrm{~N}$ is observed in many aquatic food webs such that more depleted pelagic carbon sources tend to be enriched in $\delta^{15} \mathrm{~N}$ over enriched benthic carbon sources (Abrantes \& Sheaves 2010). Although not always statistically significant, this trend was seen for each of the consumers in our study. This trend could confound apparent relationships between $\delta^{15} \mathrm{~N}$ and flooding, so we produced models using both raw $\delta^{15} \mathrm{~N}$ and corrected $\delta^{15} \mathrm{~N}$ values (residuals from regressions between consumer $\delta^{13} \mathrm{C}$ and $\delta^{15} \mathrm{~N}$ ) in regressions between $\delta^{15} \mathrm{~N}$ and flooding (Abrantes \& Sheaves 2010). The correction allowed us to separate real differences in trophic level among sites from differences driven by spatial patterns in the use of benthic versus pelagic carbon sources with different basal $\delta^{15} \mathrm{~N}$ (France 1995, Post 2002).

\section{RESULTS}

\section{Spatio-temporal patterns of marsh surface flooding}

GoM sites showed greater spatial and temporal variability in the duration of marsh surface flooding than Atlantic sites (Fig. 4a,b). Leading up to our sampling dates, the marsh surface was flooded more during the day than at night in the GoM, while the Atlantic sites were consistently flooded for slightly longer during the night than day. The marsh edges in the western GoM (Aransas and Galveston Bays, Texas) and Pamlico Sound (North Carolina), were flooded to a depth $>5 \mathrm{~cm}$ (EFI) almost continuously during the spring and early summer (Fig. 4a). Other GoM sites were more variable (30 to $90 \%$ edge flooding duration depending on the metric), while southern Atlantic marsh edges were consistently flooded from 50 to $60 \%$ of the time regardless of the diel or time period considered. Night time FAIs were not highly correlated with the corresponding night time EFI (Table 1); however, the FAI metrics showed the 


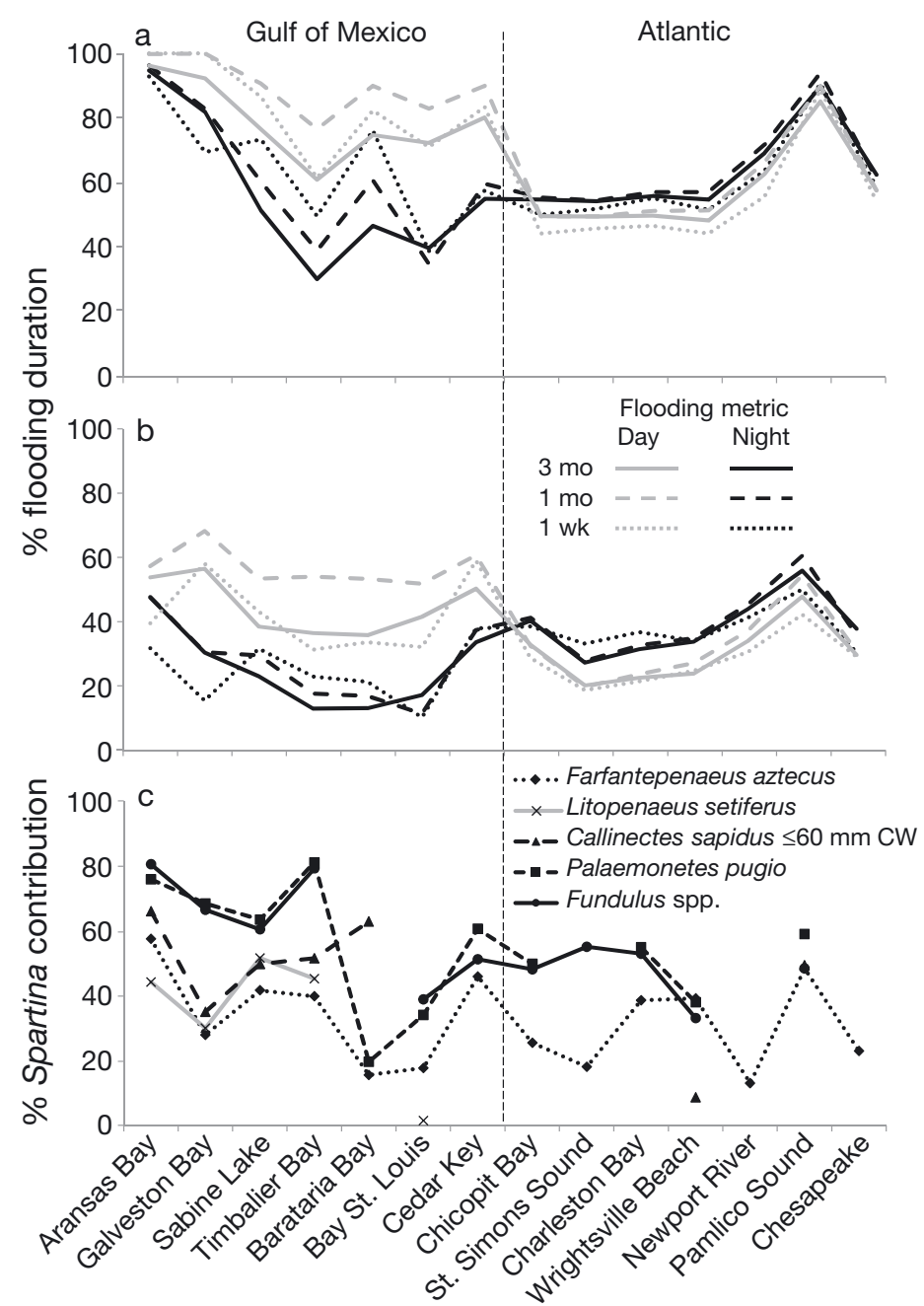

Fig. 4. Spatial patterns among saline salt marshes across the northern Gulf of Mexico and southern Atlantic coasts of the USA in (a) the duration the marsh edge is flooded to $\geq 5 \mathrm{~cm}$ depth (edge-flooded index), (b) marsh flooding based on flood-area index, and (c) estimated contributions of Spartina to the support of consumers

same broad patterns as described above for EFI (Fig. 4a,b). Within both the EFI and FAI metrics, the longer-term measures over 3 mo and 1 mo were highly correlated, while indices for the $1 \mathrm{wk}$ prior to sampling tended to deviate from these.

\section{Food web structure}

We examined relationships between $\delta^{13} \mathrm{C}$ or $\delta^{34} \mathrm{~S}$ and size among individuals for each taxon on a site by site basis to look for evidence of ontogenetic shifts in diet that may confound apparent spatial patterns among sites. Samples of mullet Mugil cephalus and M. curema and blue crab Callinectes sapidus spanned a broad size range across sites (Table S1) and showed signs of ontogenetic shifts within the size ranges we sampled. Small mullet tended to be more depleted in $\delta^{13} \mathrm{C}$ and enriched in $\delta^{34} \mathrm{~S}$ than large mullet sampled from the same sites, with medium mullet in between. Therefore, Mugil spp. were split into 3 size classes: $<50,50$ to 100 , and $>100 \mathrm{~mm}$ total length. C. sapidus was divided into 2 size classes: $\leq 60$ and $>60 \mathrm{~mm}$ carapace width (CW), with small blue crabs showing more variable isotopic values than larger crabs from the same sites (Fig. S1, Tables S2-S4 in the Supplement www.int-res.com/articles/suppl/m490p037_supp.xls). The size range of individuals within other consumer taxa was relatively narrow, and these taxa showed no evidence of ontogenetic shifts in isotopic values.

The final end-member values enclosed most consumers (Fig. 3, Fig. S1) and were similar to previously published isotopic values for the 3 dominant producers we considered (Fig. 2a). Thus we could derive solutions of the potential contribution of these 3 sources for most consumers across most sites. The $\delta^{34} \mathrm{~S}$ values of the MPB end-member tended to be similar to or lower than the few previously published values (Fig. 2a). Our generalized 3source model was a poor fit for the food web at West Bay (Panama City, Florida; Fig S1), with Farfantepenaeus aztecus, in particular, more enriched in $\delta^{13} \mathrm{C}$ than Spartina (Fig. S1, Table S2). Because of the dominance of seagrass and the structure of the food web at West Bay (see Discussion), this site was not considered comparable to the other sites for food web comparisons, and was excluded from further formal analyses. Bay St. Louis also deviated from the remaining sites but was retained in all further analyses. While this site showed a broader range of $\delta^{13} \mathrm{C}$ values, and included consumers with more depleted $\delta^{13} \mathrm{C}$ than at other sites (Fig. S1, Table S2), the food web was consistent with our 3source model. MPB and phytoplankton source values were more depleted in $\delta^{13} \mathrm{C}$ than at other sites (Fig. S1), but were still within the ranges reported from other estuaries in the region (Fig. 2).

The consumer isotopic values were consistent with our a priori classification of trophic guilds (Fig. 3). Fishery species showed intermediate values, with each source typically predicted to contribute between 20 and $50 \%$ (Table 1, Fig. 4c). Marsh surfacespecialists generally had the highest contributions of Spartina (mostly $>50 \%$ and up to $80 \%$; Fig. 4 c). The filter-feeding invertebrates and planktivorous fishes collectively showed the most depleted $\delta^{13} \mathrm{C}$ and 
Table 1. Correlation matrix including flooding indices (upper part; bold: $r>0.09$ ) and contribution of Spartina in the diet of consumers (lower part; bold: $r>0.05$ ) at salt marshes spanning the northern Gulf of Mexico and southern Atlantic coasts of the USA. Indices-EFI: edge-flooded index; FAI: flood-area index; N: night; D: day; 3m: 3 mo; $1 \mathrm{~m}$ : 1 mo; $1 \mathrm{w}$ : 1 wk. Headings in first row and vertical shading group the 3 temporal periods by flooding index and diel period. Consumers: Farfantepenaeus aztecus (Fazt); Litopenaeus setiferus (Lset); small Callinectes sapidus ( $\leq 60 \mathrm{~mm}$ carapace width) (CsapS); large C. sapidus (>60 mm) (CsapL); Palaemonetes pugio (Ppug); Fundulus heteroclitus/grandis (Fhet); medium Mugil spp. (50-100 mm total length) (MugM)

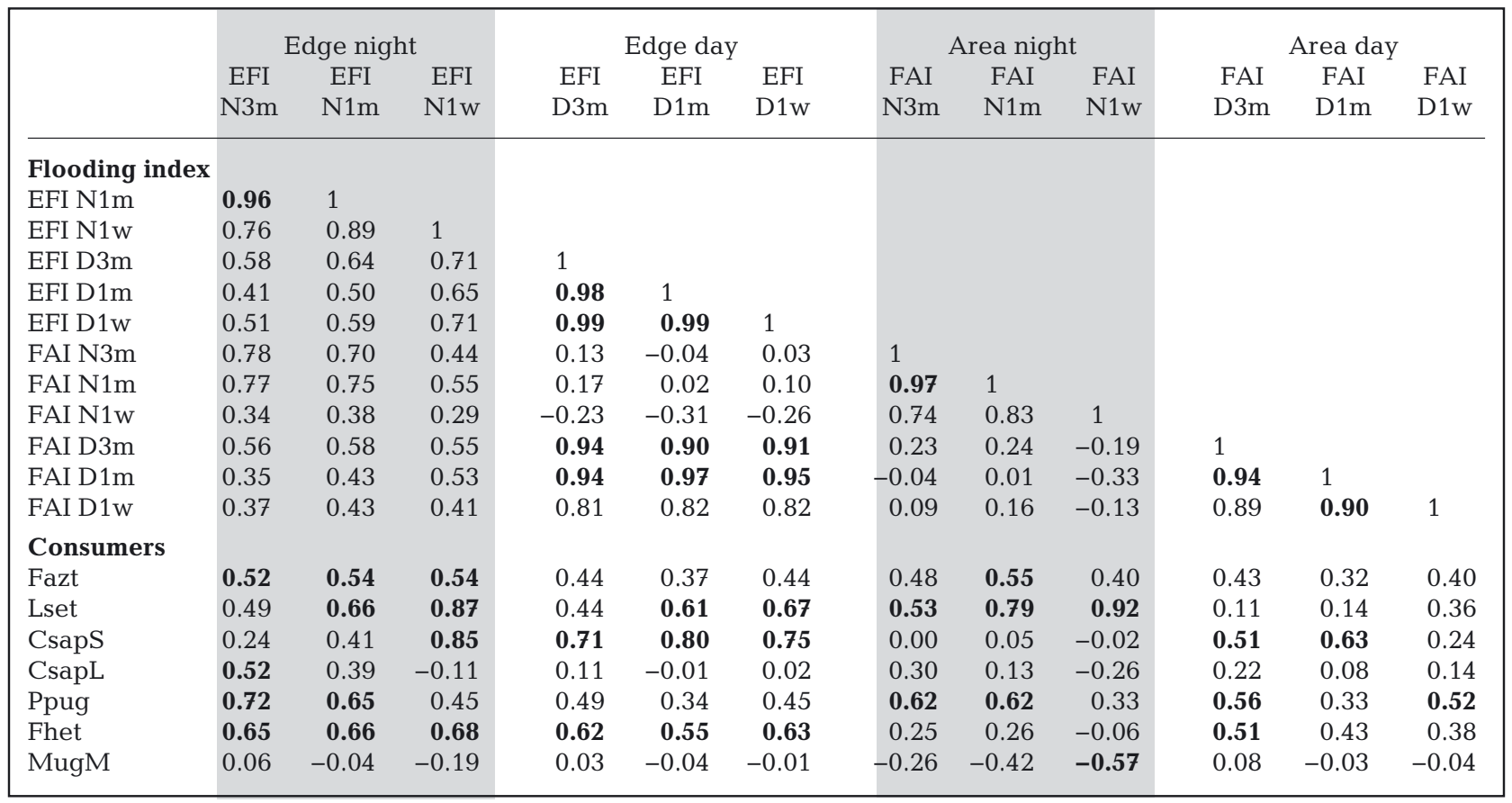

enriched $\delta^{34} \mathrm{~S}$ values, consistent with feeding on phytoplankton production (Fig. 3). While falling within the range of $\delta^{13} \mathrm{C}$ values of our 3 sources, Littoraria irrorata $\delta^{34} \mathrm{~S}$ was usually higher than source $\delta^{34} \mathrm{~S}$ values (Fig. 3). Similarly, Mugil spp. isotopic values were highly variable, often did not match closely with our local estimate of MPB source values, and several replicates fell well outside the mixing triangles (Fig. S1).

\section{Hydrodynamics and the importance of marsh production}

Five taxa (Litopenaeus setiferus, Farfantepenaeus aztecus, small $[\leq 60 \mathrm{~mm} \mathrm{CW}]$ Callinectes sapidus, Palaemonetes pugio, and Fundulus) showed positive relationships between multiple indices of marsh flooding duration and the potential contribution of Spartina (Table 1, Fig. 5). At least 1 of the regressions was significant $(0.03<\mathrm{p}<0.05)$ for all of these species (Fig. 5). Timbalier Bay (Louisiana) was a consistent outlier in these relationships, with potential contributions of Spartina to most consumers higher than predicted for the estimated flooding duration at that site. This site had unusual topography (see 'Materials and methods'), and we did not include the Timbalier Bay data in the correlation matrix (Table 1), nor in the regression models (except for $L$. setiferus, being 1 of only 5 data points), but the data point is shown in each figure (Fig. 5). Nighttime flooding indices explained more variation in Spartina contribution (higher $\mathrm{r}$ values) than the corresponding daytime indices for the 2 penaeid shrimps (Table 1). The reverse was true for small C. sapidus; although the strongest correlation between Spartina contributions and flooding was for the EFI calculated for nighttime over the $1 \mathrm{wk}$ prior to sampling $(\mathrm{r}=0.85)$, most $\mathrm{r}$ values were higher for daytime than the corresponding nighttime indices (Table 1). Fundulus and P. pugio showed positive relationships $(\mathrm{r}>0.5)$ between some measures of both daytime and nighttime flooding duration and Spartina contributions, with neither diel period showing clearly stronger relationships. Our analyses detected no apparent relationship between flooding duration and Spartina contribution for large C. sapidus or the medium Mugil spp. that fit the mixing models (Table 1). 
We found a significant negative relationship between Fundulus $\delta^{15} \mathrm{~N}$ values and flooding duration for models using both raw $\delta^{15} \mathrm{~N}\left(\mathrm{p}=0.04, \mathrm{R}^{2}=0.44\right)$, and corrected $\delta^{15} \mathrm{~N}\left(\mathrm{p}=0.04, \mathrm{R}^{2}=0.43\right.$; Fig. 5f). The models predicted Fundulus $\delta^{15} \mathrm{~N}$ to be enriched at the least flooded sites by around $2.5 \%$ o (raw $\delta^{15} \mathrm{~N}$ ) or $2.3 \%$ (corrected $\delta^{15} \mathrm{~N}$ ) compared to the most flooded sites. The other nekton showed similar but weak and non-significant trends, with flooding relationships explaining $<1 \%$ shift in $\delta^{15} \mathrm{~N}$ among the sites.

Using a trophic enrichment factor (TEF) of $2.2 \%$, trophic level estimates for the 5 target consumers
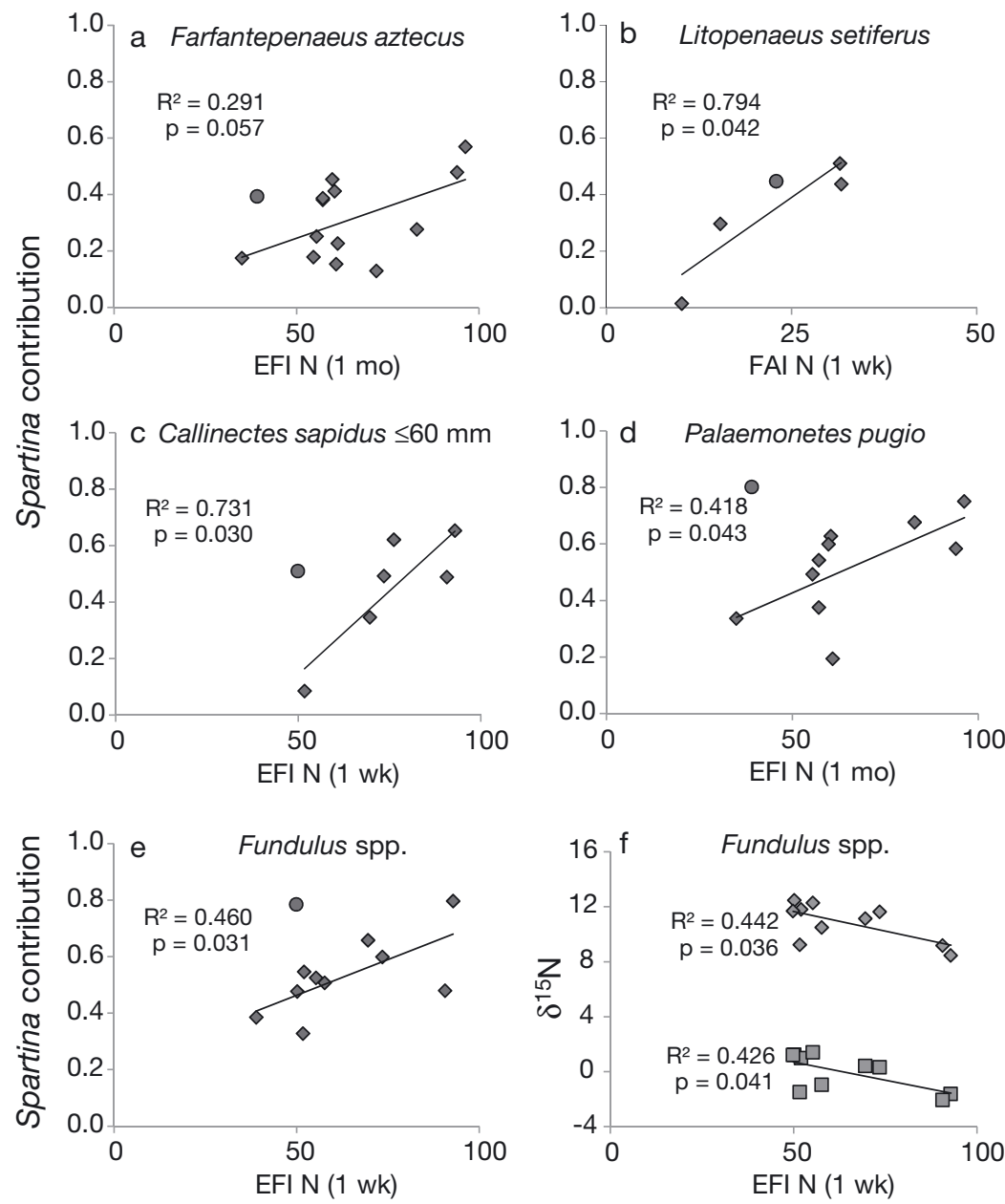

Flooding duration

Fig. 5. Relationship between marsh surface flooding duration and (a-e) the potential contribution of Spartina to the trophic support of nekton, and (f) trophic level of Fundulus grandis/heteroclitus (diamonds: raw $\delta^{15} \mathrm{~N}$, squares residual $\delta^{15} \mathrm{~N}$ as explained in the 'Materials and methods'). $x$-axes indicate the specific flooding duration index; EFI: edge-flooded index; FAI: flood-area index; N: night; durations (1 wk, $1 \mathrm{mo}$ ) as defined in the 'Materials and methods'. Circles in (a-e) are data points for Timbalier Bay, excluded from all regression models except (b)

\section{DISCUSSION}

\section{Hydrological regulation of marsh production transfer}

Marsh surface flooding patterns vary substantially across the northern GoM and southern Atlantic coasts of the USA, and these hydrological differences appear to affect the transfer of marsh production into aquatic food webs. Juvenile nekton recruiting during spring or early summer to marshes in North Carolina, for example, would gain almost continuous access to the vegetated marsh if they enter Pamlico Sound, while those recruiting around Wrightsville Beach and farther south would have access for only about half that time. Similarly, diurnally active nekton in northern GoM estuaries have access to the vegetated marsh for up to $30 \%$ more time during spring and early summer than their nocturnally active counterparts. The spatial and temporal variability in marsh flooding means that individuals from a single offshore-spawned cohort recruiting to different parts of the coast, or subsequent cohorts recruiting to the same marshes, may encounter substantially different habitat availability.

Our data provide evidence that the high densities of several species of common nekton found in flooded marsh habitats are supported by a ${ }^{13} \mathrm{C}$-enriched source, most likely Spartina. The positive correlation between the potential importance of 


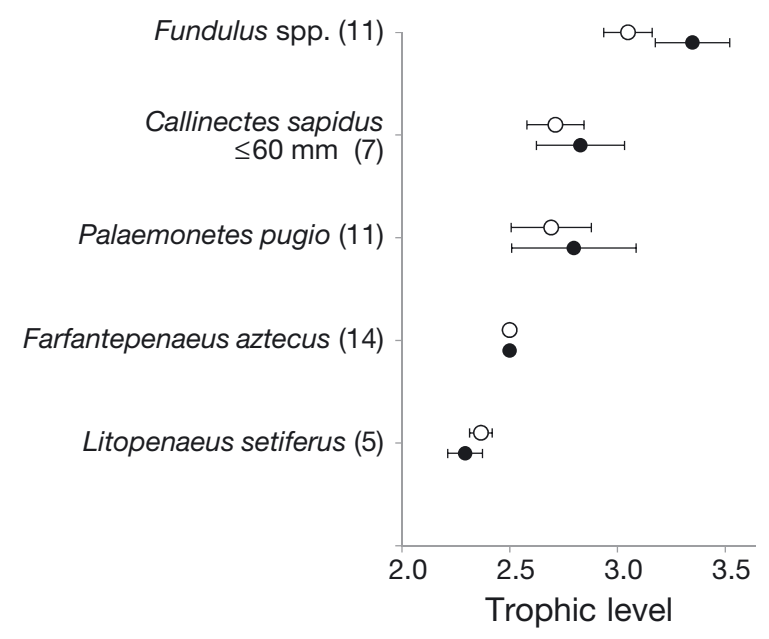

Fig. 6. Trophic level estimates for consumers sampled from salt marshes across the northern Gulf of Mexico and southern Atlantic coasts of the USA, based on $\delta^{15} \mathrm{~N}$ values. Filled circles assumed a trophic enrichment factor of $2.2 \%$ (McCutchan et al. 2003), open circles assumed 3.4\%o (Post 2002). Both estimates used Farfantepenaeus aztecus $\delta^{15} \mathrm{~N}$ as the baseline for each site with an assumed trophic level of 2.5. Data are means of site means, error bars are $95 \%$ confidence intervals. Sample sizes (number of sites) are in parentheses

Spartina and flooding duration suggests that direct access to the marsh surface is important to these taxa. If either outwelling or trophic relay were the dominant pathway linking Spartina to the consumers studied here, we would predict the reverse relationships with more Spartina delivered at less flooded sites with larger tidal amplitudes, more frequent flushing, and longer durations when intermediate prey are forced into open waters. The hydrologicallymediated foraging movements to and from the marsh surface by the nekton studied here may form a critical link in the trophic relay connecting marsh surface food webs to adjacent marine systems (Kneib 2000). Foraging movements of predators that feed on these nekton in adjacent open waters, and life-cycle migrations of these nekton and their predators, facilitate the transfer of salt marsh production across ecosystem boundaries at a variety of spatial and temporal scales (Deegan et al. 2000, Sheaves 2009). The lifecycle migrations of nekton such as penaeid shrimps may facilitate the delivery of marsh production to highlevel offshore predators through relatively short food chains (Deegan 1993, Abrantes \& Sheaves 2009).

Our results complement earlier findings that nekton with access to the marsh surface have fuller guts (Weisberg et al. 1981, Ryer 1987, Rozas \& La Salle 1990, Potthoff \& Allen 2003) and grow faster (Weisberg \& Lotrich 1982, Javonillo et al. 1997, Minello et al. 2003) than those restricted to subtidal habitats. Our models further suggest that while the provisioning function of marsh access is a general phenomenon, the magnitude of the production transfer to aquatic consumers shows substantial geographic and temporal variability driven by variable flooding of the marsh surface. If access to the vegetated marsh surface provides the benefit of increased foraging opportunities or reduced risk of predation (Boesch \& Turner 1984, Deegan et al. 2000), then the value of salt marsh to nekton varies substantially through space and time.

The consumer isotope data and mixing model outputs support our a priori classifications of trophic guilds, except for Mugil spp. (see 'Assumptions and alternatives' below), and match with isotope data reported for these consumers from elsewhere (Peterson \& Howarth 1987, Fantle et al. 1999, Dittel et al. 2000, McMahon et al. 2005, Winemiller et al. 2007, Fry 2008). Our generalist consumers of fisheries significance had intermediate contributions of the 3 sources, tending to rely more on benthic than planktonic production. At most sites, combined benthic production was estimated to contribute between 70 and $90 \%$ of the trophic support for these nekton. The marsh surface specialists, grass shrimp and killifish, generally had the highest estimated contributions from Spartina, and like the generalists, relied heavily on benthic production. The isotope data and trophic level estimates were also consistent with the known diets of these consumers (e.g. Kneib \& Stiven 1978, Weisberg et al. 1981, Kneib 1985, Rozas \& LaSalle 1990, McTigue \& Zimmerman 1991, 1998, Gregg \& Fleeger 1998, Beseres \& Feller 2007). Likewise, filterfeeding invertebrates and planktivorous fishes had isotopic values consistent with feeding primarily on phytoplankton production, hence their use as a guild to define a phytoplankton end-member.

The negative relationship between Fundulus $\delta^{15} \mathrm{~N}$ and flooding duration suggests that killifish are feeding at lower trophic levels at more flooded sites. However, variability in trophic fractionation of $\delta^{15} \mathrm{~N}$ may also be involved. We were unable to obtain direct measurements of phytoplankton (or MPB) $\delta^{15} \mathrm{~N}_{i}$ however, the trends in Spartina isotopic values during decomposition (Currin et al. 1995, Fig. 3) and the relationships between $\delta^{13} \mathrm{C}$ and $\delta^{15} \mathrm{~N}$ in our consumer data indicate that the detrital Spartina entering the food web had lower $\delta^{15} \mathrm{~N}$ than phytoplankton (and lower than measured in standing dead Spartina). This could confound the apparent relationship between marsh flooding and trophic level, since our models indicate that killifish relied more on ${ }^{15} \mathrm{~N}$ - 
enriched phytoplankton at less flooded sites and more on ${ }^{15} \mathrm{~N}$-depleted Spartina at more flooded sites. Therefore, killifish from less flooded sites should have enriched $\delta^{15} \mathrm{~N}$ over those from more flooded sites even if they were feeding at the same trophic level. However, after correcting for differences in basal $\delta^{15} \mathrm{~N}$, killifish still show a significant relationship between flooding and $\delta^{15} \mathrm{~N}$. If $\delta^{15} \mathrm{~N}$ fractionation is approximately constant among sites and among food chains leading to killifish, then the marsh food chains leading to killifish are shorter than the planktonic food chains, indicating a more efficient transfer of marsh than planktonic production to killifish.

\section{Assumptions and alternatives}

We have simplified a complex system in our triangle food web analysis to address our key aim by including only 3 dominant production sources, which account for most of the primary production of marshes in the region (Sullivan \& Moncreiff 1988). We aggregated sources into 3 groups; however, other sources may also be important. Epiphytic and filamentous algae, together with MPB, are important sources for a variety of consumers (Sullivan \& Moncreiff 1990, Currin et al. 1995). The 3 groups show similar isotopic values (Currin et al. 1995, Galvan et al. 2008), and hence our MPB end-member also serves as a proxy for these benthic and epiphytic production sources. Similarly, cyanobacteria may occur on tidal flats and the marsh surface, and can have enriched $\delta^{13} \mathrm{C}$ values similar to Spartina (Pulich \& Scalan 1987, Currin et al. 1995). Even if an alternative source such as cyanobacteria is contributing to the input attributed to Spartina in our models, the correlations with marsh flooding mean that such a source likely occurs primarily in the intertidal zone, which throughout the region is dominated by salt marsh. As such, our conclusions about hydrodynamic regulation of the transfer of marsh production to aquatic food webs would remain valid. Because of the potential contributions from other producers, the results of our mixing models should not be interpreted as precise estimates of the actual contributions of each source. Rather, assuming that the 3 producers used in our models are important to the nekton studied (e.g. Riera et al. 2000, Wainright et al. 2000, McMahon et al. 2005, Winemiller et al. 2007), then our results represent the maximum potential contribution of each source (Fry 2006).

There was a degree of subjectivity in determining the precise end-member values for each site. The final values, however, agree broadly with the original predictions from the literature, were based on direct empirical data wherever possible, and were set prior to running any mixing models. The data for some taxa were derived from small sample sizes; however, all except Mugil spp. and large Callinectes sapidus showed positive relationships between multiple measures of marsh flooding duration and the potential contribution of Spartina. Mugil spp. often did not match with our local estimates of MPB source values, and at a few sites did not fit within the 3source models. The smallest size class $(<50 \mathrm{~mm})$ tended to have enriched $\delta^{34} \mathrm{~S}$ values, possibly because small juveniles feed on planktonic prey before an ontogenetic shift to benthic feeding at larger sizes (Gisbert et al. 1995). The broad range in $\delta^{13} \mathrm{C}$ values of larger Mugil could reflect high mobility of these individuals allowing them to feed on resources across a range of habitats with, for example, widely varying salinities (e.g. Fry 2002). Similarly, the lack of a relationship between marsh flooding and isotopic values for larger C. sapidus could be indicative of larger-scale movements by these crabs among habitats with different source values, or of feeding primarily on non marsh-surface sources (Williams et al. 1990). The elevated $\delta^{34} \mathrm{~S}$ values of Littoraria above the sources included in the mixing model could be driven by selective feeding on the microbial communities decomposing standing dead Spartina. These microbes gradually incorporate enriched sulfate from the water column to replace the original plant tissues which also incorporated more depleted sulfides from the sediments during plant growth (Newell et al. 1989, Currin et al. 1995). A further consequence of this process is that the $\delta^{34} \mathrm{~S}$ of detrital Spartina entering the food web at many sites was quite likely enriched over the values measured in standing dead plants (Fig. 3). No lipid extraction or normalization was performed on the isotope samples or data. The only consumers with $\mathrm{C}: \mathrm{N}$ regularly above 3.5 (generally around 4), indicating a lipid content that may bias $\delta^{13} \mathrm{C}$ values (Post et al. 2007), were barnacles, filter-feeding bivalves, and Littoraria. Littoraria values mostly fell outside our mixing triangles and hence we were unable to estimate source contributions for them in any case. The other invertebrates with high $\mathrm{C}: \mathrm{N}$ were used together with planktivorous fishes and published data to define a phytoplankton end-member. The approach of using both top-down (i.e. target consumer data) and bottom-up (producer data and published values) inference to set source values in our mixing models (see below) accounts for any minor 
trophic fractionations or depletion due to lipid content (Wissel \& Fry 2005).

White shrimp Litopenaeus setiferus were sampled from only 5 sites in the central and western GoM. Recruitment of juvenile L. setiferus into marsh habitats apparently had not yet commenced at the more eastern and northern sites when we collected the samples in early to mid-June (Lindner \& Anderson 1956). Regressions based on so few data points must obviously be interpreted with caution; however, the consistent trends between flooding metrics and the potential contribution of Spartina give confidence that the relationships are not spurious. For each metric, those calculated for the $1 \mathrm{wk}$ prior to sampling provided the strongest correlation, whereas those for the 3 mo prior to sampling gave the weakest. This pattern is as expected for fast-growing juveniles (Baker \& Minello 2010) whose biomass, and hence isotopic signatures, are dominated by recent growth (Hesslein et al. 1993).

The food web structure and isotopic values of consumers spanned a similar range across most sites except for West Bay in Florida, and Bay St. Louis in Mississippi. In West Bay, 2 of the Farfantepenaeus aztecus replicates were more enriched in $\delta^{13} \mathrm{C}$ than the local Spartina. This could indicate almost exclusive reliance on Spartina production, with trophic fractionation accounting for the enrichment. However, unlike all other sites, this site had only a narrow fringe of Spartina marsh backing a clearwater bay containing extensive seagrass beds. The shrimp collected from this site were found in the seagrass rather than in or immediately adjacent to the marsh as at all other sites, and the isotopic signature of shrimp at this site was likely dominated by seagrass. While this site was useful for examining relationships between marsh elevation and tidal datums in the models of Minello et al. (2012), it was excluded from the current food web analyses. The food web at Bay St. Louis was consistent with our 3-source model, with phytoplankton and MPB sources more depleted in $\delta^{13} \mathrm{C}$ than at other sites. This depletion likely reflects an effect of salinity (Fry 2002), since this site had the lowest salinity at the time of sampling (authors' unpublished data), and appears to remain at low salinity through much of the year (Rozas \& LaSalle 1990). The depletion of aquatic producers at this site could also be partially driven by inputs of ${ }^{13} \mathrm{C}$-depleted allochthonous organic material, such as detritus from a C3plant dominated catchment (Abrantes et al. 2013).

Timbalier Bay consumers had isotopic values within the range sampled from most other sites, yet the estimated contribution of Spartina at this site was consistently higher than expected for the estimated flooding duration. This suggests that either the food web at this site functions differently from other sites, or that our models over-estimated the contribution of Spartina, or underestimated the duration of access to the marsh surface. Of these, our estimate of marsh access is perhaps the most likely to be erroneous. Of all sites, Timablier Bay had the most pronounced berm within the first $10 \mathrm{~m}$ of vegetation, behind which the marsh surface was a similar elevation to the edge (Minello et al. 2012). If nekton can access the lower marsh surface behind the berm via small creeks or drainages before the berm is overtopped, then our metric of flooding duration would underestimate the duration of availability of the marsh surface. All other sites showed only minor dips in elevation after the initial step onto the marsh platform, or continued to increase in elevation inland from the marsh edge. Our indices of marsh flooding appear to generally represent access for nekton to the marsh surface, but remain simplified measures of accessibility across a 3-dimensional landscape. Despite the potentially limited application of these simple flooding metrics at sites with more variable and complex topography, our models highlight the underlying mechanism of hydrological regulation of marsh production transfer to aquatic food webs.

\section{CONCLUSIONS}

In addition to the role of hydrology in regulating the contribution of marsh production to aquatic food webs, a range of biological and physical factors, such as seascape configuration, consumer and prey population dynamics, and movement patterns driven by the need for food, refuge, and favorable physical conditions, combine to structure the trophic dynamics in these systems. The taxa we studied are, to varying degrees, mobile organisms using a range of prey resources across multiple habitats. The full range of processes that structure salt marsh food webs serves to add noise to the relationships between hydrology and marsh use. Despite this, and the fact that our food web and hydrology models are simplifications of complex systems, we found a clear link between the duration of marsh surface flooding and the magnitude of marsh production in supporting aquatic consumers. Although this is exactly what paradigms of salt marsh ecology predict (Boesch \& Turner 1984, Deegan et al. 2000, Kneib 2000), previous evidence of the importance of the marsh surface for feeding has been limited to a few species- and site-specific 
studies. The models of the present study, together with those of Minello et al. (2012), make clear and testable predictions about temporal and geographic patterns in marsh surface flooding and the effects this should have on trophic dynamics. For example, salt marshes across the central and western GoM coasts of the USA experience considerable shortterm (week to week) variation in marsh flooding. Our models predict that the variability in marsh access would regulate the importance of Spartina production for nekton, and that this would be measurable in the isotopic values of small, fast-growing juveniles of nekton such as penaeid shrimps and blue crabs sampled at regular intervals from such sites. Should further work validate or strengthen our models, an important question remains. Does feeding on marsh production represent an advantage for nekton over feeding on alternative, non-marsh sources? In terms of the ultimate relevance to the sustainability of populations, this question is difficult to answer; however, more proximate evidence could be examined. If feeding on marsh production is advantageous, we might predict that individuals at locations or times with greater marsh access will have higher growth rates or be more fecund than those with less access to the marsh surface. Although measuring these demographic rates directly is logistically difficult, the information from such research would advance our understanding of the marsh provisioning function. Addressing such questions across multiple sites will help elucidate the processes and mechanisms regulating habitat use, and clarify geographic and temporal variability in marsh value and nursery function.

Acknowledgements. We thank K. Galvan, K. Abrantes, and 3 anonymous reviewers for comments and advice that greatly improved this manuscript; S. Hillen (NOAA Galveston) for preparing samples for isotope analysis; and P. Caldwell (NOAA Galveston) for producing Fig. 1. This research was partially supported by funding from M. Croom and the Southeast Regional Habitat Office of the National Marine Fisheries Service. This research was performed while R.B. held a National Research Council Research Associateship Award at the NOAA Galveston Laboratory. The findings and conclusions in this paper are those of the authors and do not necessarily represent the views of the National Marine Fisheries Service.

\section{LITERATURE CITED}

Abrantes K, Sheaves M (2009) Sources of nutrition supporting juvenile penaeid prawns in an Australian dry tropics estuary. Mar Freshw Res 60:949-959

> Abrantes K, Sheaves M (2010) Use of a $\delta^{13} \mathrm{C}-\delta^{15} \mathrm{~N}$ relationship to determine animal trophic positions in a tropical Australian estuarine wetland. Austral Ecol 35:96-103
Abrantes KG, Barnett A, Marwick TR, Bouillon S (2013) Importance of terrestrial subsidies for estuarine food webs in contrasting East African catchments. Ecosphere 4:art14

> Baker R, Minello TJ (2010) Growth and mortality of juvenile white shrimp Litopenaeus setiferus in a marsh pond. Mar Ecol Prog Ser 413:95-104

Beseres JJ, Feller RJ (2007) Importance of predation by white shrimp Litopenaeus setiferus on estuarine subtidal macrobenthos. J Exp Mar Biol Ecol 344:193-205

Boesch D, Turner RE (1984) Dependence of fishery species on salt marshes: the role of food and refuge. Estuaries 7 : 460-468

Brand WA (1996) High precision isotope ratio monitoring techniques in mass spectrometry. J Mass Spectrom 31: 225-235

$>$ Buchheister A, Latour RJ (2010) Turnover and fractionation of carbon and nitrogen stable isotopes in tissues of a migratory coastal predator, summer flounder (Paralichthys dentatus). Can J Fish Aquat Sci 67:445-461

Cabana G, Rasmussen JB (1996) Comparison of aquatic food chains using nitrogen isotopes. Proc Natl Acad Sci USA 93:10844-10847

Carlson PR, Forrest J (1982) Uptake of dissolved sulfide by Spartina alterniflora: evidence from natural sulfur isotope abundance ratios. Science 216:633-635

Cattrijsse A, Hampel H (2006) European intertidal marshes: a review of their habitat functioning and value for aquatic organisms. Mar Ecol Prog Ser 324:293-307

Caut S, Angulo E, Courchamp F (2009) Variation in discrimination factors $\left(\Delta^{15} \mathrm{~N}\right.$ and $\left.\Delta^{13} \mathrm{C}\right)$ : the effect of diet isotopic values and applications for diet reconstruction. J Appl Ecol 46:443-453

Cicchetti G, Diaz RJ (2000) Types of salt marsh edge and export of trophic energy from marshes to deeper habitats. In: Weinstein MP, Kreeger DA (eds) Concepts and controversies in tidal marsh ecology. Kluwer Academic Publishers, Dordrecht, p 515-541

Connolly RM (1999) Saltmarsh as habitat for fish and nektonic crustaceans: challenges in sampling designs and methods. Aust J Ecol 24:422-430

> Connolly RM, Guest MA, Melville AJ, Oakes JM (2004) Sulfur stable isotopes separate producers in marine foodweb analysis. Oecologia 138:161-167

> Currin CA, Newell SY, Paerl HW (1995) The role of standing dead Spartina alterniflora and benthic microalgae in salt marsh food webs: considerations based on multiple stable isotope analysis. Mar Ecol Prog Ser 121:99-116

Currin CA, Wainright SC, Able KW, Weinstein MP, Fuller CM (2003) Determination of food web support and trophic position of the mummichog, Fundulus heteroclitus, in New Jersey smooth cordgrass (Spartina alterniflora), common reed (Phragmites australis), and restored salt marshes. Estuaries 26:495-510

> Currin CA, Levin LA, Talley TS, Michener R, Talley D (2011) The role of cyanobacteria in Southern Californian salt marsh food webs. Mar Ecol 32:346-363

> Deegan LA (1993) Nutrient and energy transport between estuaries and coastal marine ecosystems by fish migration. Can J Fish Aquat Sci 50:74-79

Deegan LA, Hughes JE, Rountree RA (2000) Salt marsh ecosystem support of marine transient species. In: Weinstein MP, Kreeger DA (eds) Concepts and controversies in tidal marsh ecology. Kluwer Academic Publishers, Dordrecht, p 333-365 
Demopoulos AWJ, Cormier N, Ewel KC, Fry B (2008) Use of multiple chemical tracers to define habitat use of IndoPacific mangrove crab, Scylla serrata (Decapoda: Portunidae). Estuar Coast 31:371-381

Dittel AI, Epifanio CE, Schwalm SM, Fantle MS, Fogel ML (2000) Carbon and nitrogen sources for juvenile blue crabs Callinectes sapidus in coastal wetlands. Mar Ecol Prog Ser 194:103-112

Fantle MS, Dittel AI, Schwalm SM, Epifanio CE, Fogel ML (1999) A food web analysis of the juvenile blue crab, Callinectes sapidus, using stable isotopes in whole animals and individual amino acids. Oecologia 120:416-426

Fogel ML, Cifuentes LA, Velinsky DJ, Sharp JH (1992) Relationship of carbon availability in estuarine phytoplankton to isotopic composition. Mar Ecol Prog Ser 82: 291-300

> France RL (1995) Carbon-13 enrichment in benthic compared to planktonic algae: foodweb implications. Mar Ecol Prog Ser 124:307-312

> Fry B (2002) Conservative mixing of stable isotopes across estuarine salinity gradients: a conceptual framework for monitoring watershed influences on downstream fisheries production. Estuaries 25:264-271

Fry B (2006) Stable isotope ecology. Springer, Heidelberg

> Fry B (2007) Coupled N, C, and S isotope measurements using dual column GC system. Rap Comm Mass Spectrom 21:750-756

> Fry B (2008) Open bays as nurseries for Louisiana brown shrimp. Estuar Coast 31:776-789

> Fry B (2013) Alternative approaches for solving underdetermined isotope mixing problems. Mar Ecol Prog Ser 472: $1-13$

> Fry B, Chumchal MM (2012) Mercury bioaccumulation in estuarine food webs. Ecol Appl 22:606-623

Fry B, Baltz DM, Benfield MC, Fleeger JW, Gace A, Haas HL, Quiñones-Rivera ZJ (2003) Stable isotope indicators of movement and residency for brown shrimp (Farfantepenaeus aztecus) in coastal Louisiana marshscapes. Estuaries 26:82-97

> Galvan K, Fleeger JW, Fry B (2008) Stable isotope addition reveals dietary importance of phytoplankton and microphytobenthos to salt marsh infauna. Mar Ecol Prog Ser 359:37-49

Gisbert E, Cardona L, Castello F (1995) Competition between mullet fry. J Fish Biol 47:414-420

> Gonzalez I, Levin M, Jermanus S, Watson B, Glig MP (2009) Genetic assessment of species ranges in Fundulus heteroclitus and $F$. grandis in northeastern Florida salt marshes. Southeast Nat 8:227-243

> Gregg CS, Fleeger JW (1998) Grass shrimp Palaemonetes pugio predation on sediment- and stem-dwelling meiofauna: field and laboratory experiments. Mar Ecol Prog Ser 175:77-86

Hesslein RH, Hallard KA, Ramlal P (1993) Replacement of sulfur, carbon, and nitrogen in tissue of growing broad whitefish (Coregonus nasus) in response to a change in diet traced by $\delta^{34} \mathrm{~S}, \delta^{13} \mathrm{C}$ and $\delta^{15} \mathrm{~N}$. Can J Fish Aquat Sci 50:2071-2076

Javonillo R, Deegan L, Chiaravalle K, Hughes J (1997) The importance of access to salt-marsh surface to short-term growth of Fundulus heteroclitus in a New England salt marsh. Biol Bull (Woods Hole) 193:288-289

Kneib RT (1985) Predation and disturbance by grass shrimp, Palaemonetes pugio Holthuis, in soft-substratum benthic invertebrate assemblages. J Exp Mar Biol Ecol 93:91-102
Kneib RT (1991) Flume weir for quantitative collection of nekton from vegetated intertidal habitats. Mar Ecol Prog Ser 75:29-38

Kneib RT (1997) The role of tidal marshes in the ecology of estuarine nekton. Oceanogr Mar Biol Annu Rev 35: $163-220$

Kneib RT (2000) Salt marsh ecoscapes and production transfers by estuarine nekton in the southeastern United States. In: Weinstein MP, Kreeger DA (eds) Concepts and controversies in tidal marsh ecology. Kluwer Academic Publishers, Dordrecht, p 267-291

- Kneib RT, Stiven AE (1978) Growth, reproduction, and feeding of Fundulus heteroclitus (L.) on a North Carolina salt marsh. J Exp Mar Biol Ecol 31:121-140

> Kneib RT, Wagner SL (1994) Nekton use of vegetated marsh habitats at different stages of tidal inundation. Mar Ecol Prog Ser 106:227-238

Lindner MJ, Anderson WW (1956) Growth, migrations, spawning and size distribution of shrimp Penaeus setiferus. Fish Bull 56:555-645

McCutchan JH, Lewis WM, Kendall C, McGrath CC (2003) Variation in trophic shift for stable isotope ratios of carbon, nitrogen, and sulfur. Oikos 102:378-390

McMahon KW, Johnson BJ, Ambrose WG Jr (2005) Diet and movement of the killifish, Fundulus heteroclitus, in a Maine salt marsh assessed using gut contents and stable isotope analyses. Estuaries 28:966-973

McTigue TA, Zimmerman RJ (1991) Carnivory vs herbivory in juvenile Penaeus setiferus (Linnaeus) and Penaeus aztecus (Ives). J Exp Mar Biol Ecol 151:1-16

McTigue TA, Zimmerman RJ (1998) The use of infauna by juvenile Penaeus aztecus Ives and Penaeus setiferus (Linnaeus). Estuaries 21:160-175

Minello TJ (1999) Nekton densities in shallow estuarine habitats of Texas and Louisiana and the identification of essential fish habitat. Am Fish Soc Symp 22:43-75

Minello TJ, Zimmerman RJ, Martinez EX (1989) Mortality of young brown shrimp Penaeus aztecus in estuarine nurseries. Trans Am Fish Soc 118:693-708

Minello TJ, Able KW, Weinstein MP, Hays CG (2003) Salt marshes as nurseries for nekton: testing hypotheses on density, growth and survival through meta-analysis. Mar Ecol Prog Ser 246:39-59

Minello TJ, Matthews GA, Caldwell PA, Rozas LP (2008) Population and production estimates for decapod crustaceans in wetlands of Galveston Bay, Texas. Trans Am Fish Soc 137:129-146

> Minello TJ, Rozas LP, Baker R (2012) Geographic variability in salt marsh flooding patterns may affect nursery value for fishery species. Estuar Coast 35:501-514

> Newell SY, Fallon RD, Miller JD (1989) Decomposition and microbial dynamics for standing, naturally positioned leaves of the salt-marsh grass, Spartina alterniflora. Mar Biol 101:471-481

Oakes JM, Revill AT, Connolly RM, Blackburn SI (2005) Measuring carbon isotope ratios of microphytobenthos using compound-specific stable isotope analysis of phytol. Limnol Oceanogr Methods 3:511-519

Peterson BJ, Fry B (1987) Stable isotopes in ecosystem studies. Annu Rev Ecol Syst 18:293-320

> Peterson BJ, Howarth RW (1987) Carbon and nitrogen isotopes used to trace organic matter flow in the salt-marsh estuaries of Sapelo Island, Georgia. Limnol Oceanogr 32: 1195-1213

Peterson BJ, Howarth RW, Lipschultz F, Ashendorf D (1980) 
Salt marsh detritus: an alternative interpretation of stable carbon isotope ratios and the fate of Spartina alterniflora. Oikos 34:173-177

Peterson BJ, Howarth RW, Garritt RH (1986) Sulfur and carbon isotopes as tracers of salt-marsh organic matter flow. Ecology 67:865-874

Peterson GW, Turner RE (1994) The value of salt marsh edge vs. interior as a habitat for fish and decapod crustaceans in a Louisiana tidal marsh. Estuaries 17:235-262

> Post DM (2002) Using stable isotopes to estimate trophic position: models, methods, and assumptions. Ecology 83: 703-718

> Post DM, Layman CA, Arrington DA, Takimoto G, Quattrochi J, Montana CG (2007) Getting to the fat of the matter: models, methods and assumptions for dealing with lipids in stable isotope analyses. Oecologia 152:179-189

Potthoff MT, Allen DM (2003) Site fidelity, home range, and tidal migrations of juvenile pinfish, Lagodon rhomboides, in salt marsh creeks. Environ Biol Fishes 67: 231-240

Pulich WM, Scalan RS (1987) Organic carbon and nitrogen flow from marine cyanobacteria to semiaquatic insect food webs. Contrib Mar Sci 30:27-37

Riera P, Montagna PA, Kalke RD, Richard P (2000) Utilization of estuarine organic matter during growth and migration by juvenile brown shrimp Penaeus aztecus in a South Texas estuary. Mar Ecol Prog Ser 199:205-216

Rountree RA, Able KW (1992) Fauna of polyhaline subtidal marsh creeks in southern New Jersey: composition, abundance and biomass. Estuaries 15:171-185

Rountree RA, Able KW (2007) Spatial and temporal habitat use patterns for salt marsh nekton: implications for ecological functions. Aquat Ecol 41:25-45

Rozas LP (1995) Hydroperiod and its influence on nekton use of the saltmarsh: a pulsing ecosystem. Estuaries 18: 579-590

Rozas LP, LaSalle MW (1990) A comparison of the diets of gulf killifish, Fundulus grandis Baird and Girard, entering and leaving a Mississippi brackish marsh. Estuaries 13:332-336

Rozas LP, Minello TJ, Zimmerman RJ, Caldwell P (2007) Nekton populations, long-term wetland loss, and the effect of recent habitat restoration in Galveston Bay, Texas, USA. Mar Ecol Prog Ser 344:119-130

Ryer CH (1987) Temporal patterns of feeding by blue crabs (Callinectes sapidus) in a tidal-marsh creek and adjacent seagrass meadow in the lower Chesapeake Bay. Estuaries 10:136-140

Sheaves M (2009) Consequences of ecological connectivity: the coastal ecosystem mosaic. Mar Ecol Prog Ser 391: $107-115$

Sheaves M, Baker R, Johnston R (2006) Marine nurseries and effective juvenile habitats: an alternative view. Mar

Editorial responsibility: Jana Davis, Annapolis, Maryland, USA
Ecol Prog Ser 318:303-306

Shervette VR, Gelwick F (2008) Relative nursery function of oyster, vegetated marsh edge, and nonvegetated bottom habitats for juvenile white shrimp Litopenaeus setiferus. Wetl Ecol Manag 16:405-419

Sullivan MJ, Moncreiff CA (1988) Primary production of edaphic algal communities in a Mississippi salt marsh. J Phycol 24:49-58

Sullivan MJ, Moncreiff CA (1990) Edaphic algae are an important component of salt marsh food-webs: evidence from multiple stable isotope analyses. Mar Ecol Prog Ser 62:149-159

Teal JM (1962) Energy flow in the salt marsh ecosystem of Georgia. Ecology 43:614-624

- Trust BA, Fry B (1992) Stable sulphur isotopes in plants: a review. Plant Cell Environ 15:1105-1110

- Turner RE (1977) Intertidal vegetation and commercial yields of penaeid shrimp. Trans Am Fish Soc 106: 411-416

> Wainright SC, Weinstein MP, Able KW, Currin CA (2000) Relative importance of benthic microalgae, phytoplankton and the detritus of smooth cordgrass Spartina alterniflora and the common reed Phragmites australis to brackish-marsh food webs. Mar Ecol Prog Ser 200:77-91

Weisberg SB, Lotrich VA (1982) The importance of infrequently flooded intertidal marsh surface as an energy source for the mummichog Fundulus heteroclitus: an experimental approach. Mar Biol 66:307-310

Weisberg SB, Whalen R, Lotrich VA (1981) Tidal and diurnal influence on food consumption of a salt marsh killifish Fundulus heteroclitus. Mar Biol 61:243-246

Wickham DA, Minkler FC (1975) Laboratory observations on daily patterns of burrowing and locomotor activity of pink shrimp, Penaeus duorarum, brown shrimp, Penaeus aztecus, and white shrimp, Penaeus setiferus. Contrib Mar Sci 19:21-35

Williams AH, Coen LD, Stoelting MS (1990) Seasonal abundance, distribution, and habitat selection of juvenile Callinectes sapidus (Rathbun) in the northern Gulf of Mexico. J Exp Mar Biol Ecol 137:165-183

Winemiller KO, Akin S, Zeug SC (2007) Production sources and food web structure of a temperate tidal estuary: integration of dietary and stable isotope data. Mar Ecol Prog Ser 343:63-76

- Wissel B, Fry B (2005) Tracing Mississippi River influences in estuarine food webs of coastal Louisiana. Oecologia 144:659-672

Zimmerman RJ, Minello TJ, Rozas LP (2000) Salt marsh linkages to productivity of penaeid shrimps and blue crabs in the northern Gulf of Mexico. In: Weinstein MP, Kreeger DA (eds) Concepts and controversies in tidal marsh ecology. Kluwer Academic Publishers, Dordrecht, p 293-314

Submitted: March 20, 2013; Accepted: June 7, 2013

Proofs received from author(s): September 1, 2013 